\title{
Dampak Penggunaan Gadget terhadap Perkembangan Psikologi pada Anak Sekolah Dasar
}

\author{
${ }^{*}$ Layyinatus Syifa ${ }^{1}$, Eka Sari Setianingsih ${ }^{2}$, Joko Sulianto ${ }^{3}$
}

123 Jurusan Pendidikan Guru Sekolah Dasar, Universitas PGRI Semarang, Indonesia

\author{
A R T I C L E I N F 0 \\ Article history: \\ Received 15 August 2019 \\ Received in revised form \\ 20 September 2019 \\ Accepted 10 October 2019 \\ Available online 30 \\ November 2019 \\ Kata Kunci: \\ perkembangan psikologi, \\ gadget \\ Keywords: \\ psychology development, \\ gadget.
}

\begin{abstract}
A B S T R A K
Latar belakang dalam penelitian ini adalah Untuk mengetahui apakah terdapat dampak yang ditimbulkan terhadap penggunaan gadget (dampak positif maupun dampak negatif) terhadap perkembangan mental anak usia sekolah dasar di SD terutama di kelas V. Tujuan yang ingin dicapai pada penelitian ini adalah untuk mendeskripsikan dampak penggunaan gadget terhadap perkembangan psikologi anak usia sekolah dasar.Metode penelitian ini menggunakan pendekatan kualitatif, sehingga data yang dihasilkan berupa kata dan kalimat. Metode kualitatif digunakan untuk meneliti suatu kondisi obyek yang bersifat alamiah, peneliti sebagai instrumen kunci, teknik pengumpulan data dilakukan secara triangulasi (observasi, wawancara, dokumentasi), dan hasil penelitian kualitatif bersifat memahami makna, keunikan, mengkontruksi fenomena, dan menemukan hipotesis. Hasil dari penelitian ini adalah penggunaan gadget berdampak pada perkembangan psikologi anak sekolah dasar. Dalam penelitian ini 10
\end{abstract} anak di kelas $\mathrm{V}$ (lima) yang menggunakan gadget dengan durasi lebih dari 2 jam perhari mengalami perubahan perilaku. Dampak yang ditimbulkan yaitu dampak positif, anak mudah mencari informasi tentang pembelajaran, dan memudahkan untuk berkomunikasi dengan teman. Namun, dampak negatif yang ditimbulkan dari gadget, berpengaruh pada perkembangan psikologi anak, terutama aspek pertumbuhan emosi dan perkembangan moral. Dalam pertumbuhan emosi, anak yang menggunakan gadget menjadi mudah marah, suka membangkang, menirukan tingkah laku dalam gadget serta berbicara sendiri pada gadget. Sedangkan pengaruhnya terhadap perkembangan moral, berdampak pada kedisiplinan, anak menjadi malas melakukan apapun, meninggalkan kewajibannya untuk beribadah, dan berkurangnya waktu belajar akibat terlalu sering bermain game dan menonton youtube.

\begin{abstract}
A B S T R A C T
The background in this research is to find out whether there is an impact on the use of gadgets (both positive and negative impacts) on the mental development of elementary school-age children at SD Muhammadiyah 11 Semarang, especially in class $V$. The purpose of this study is to describe the impact of the use of gadgets on the psychological development of elementary school age children at SD Muhammadiyah 11 Semarang. This research method uses a qualitative approach, so that the data generated in the form of words and sentences. Therefore the role of parents towards their children must always be done. Do not let parents rely on gadgets to accompany their children, and parents let children prioritize more on gadgets so that they do not bother parents. By controlling every piece of content in their children's gadgets. Parents should be able to invite discussion in the sense of question and answer about the contents of all the gadgets that their children have. This means playing time is a useful time. Children can learn through play time. During that time children can imitate adult behavior, develop their imagination and creativity. So it can be concluded that giving gadgets to children without adult supervision or older people will indeed tend to cause some negative impacts.
\end{abstract}




\section{Pendahuluan}

Manusia mempunyai kemampuan untuk melihat masa depan. Akal pikiran manusia mampu mengembangkan ilmu pengetahuan dan menciptakan teknologi yang diinginkan. Ilmu dan teknologi saling berkaitan erat karena tanpa ilmu tidak ada penerapan baru untuk teknologi dan tanpa teknologi tidak ada yang akan menikmati penemuan ilmu. Dewasa ini, perkembangan dan kemajuan di bidang ilmu pengetahuan dan teknologi berkembang dengan pesatnya. (Ameliola, S., Nugraha, 2013) Perkembangan teknologi dan informasi di dunia mengalami kemajuan yang sangat pesat, yang di tandai dengan kemajuan pada bidang informasi dan teknologi, dan bangsa Indonesia merupakan salah satu bangsa yang ikut terlibat dalam kemajuan media informasi dan teknologi.

Berdasarkan Informasi dan Transaksi Elektronik (Undang Undang Republik Indonesia nomor 1 pasal 1 ayat 1 tahun 2008).

"Informasi elektronik adalah satu atau sekumpulan data elektronik, termasuk tetapi tidak terbatas pada tulisan, suara gambar, peta, rancangan, foto, electronic data interchange (EDI), surat elektronik (electronic mail), telegram, teleks, telecopy atau sejenisnya, huruf, tanda, angka, Kode Akses, simbol, atau perfosai yang telah diolah yang memiliki arti atau dapat dipahami oleh orang yang mampu memahaminya", dan Ayat 3 yang berbunyi " Teknologi Informasi adalah suatu teknik untuk mengumpulkan, menyiapkan, menyimpan, memproses, mengumumkan, menganalisis, dan/atau menyebarkan informasi".

Berkat perkembangan dari kemajuan IPTEK, manusia dapat menciptakan alat-alat serta perlengkapan yang canggih untuk berbagai kegiatan sehingga dalam kegiatan hidupnya tersedia berbagai kemudahan yang memungkinkan kegiatannya lebih efektif serta efisien.

Perkembangan dan kemajuan IPTEK pun disatu sisi kita merasa gembira karena kita dapat mengakses informasi dalam waktu yang relatif singkat dengan biaya yang murah, tetapi disisi lain sangat memperihatinkan karena kemajuan IPTEK semacam ini dapat menimbulkan dampak negatif bagi generasi muda khususnya para siswa. Sebagai contoh; dengan adanya perkembangan dan kemajuan IPTEK yang sedemikian canggih di bidang telekomunikasi khususnya gadget. Dengan gadget yang melalui fitur-fitur lengkap membuat pelajar mampu mengakses informasi yang ada di seluruh penjuru dunia dalam waktu yang relatif singkat dan hampir bersamaan serta dengan biaya yang relatif murah sehingga dapat membantu siswa dalam mengakses informasi yang berhubungan dengan materi-materi pembelajaran yang diberikan di sekolah alhasil prestasi belajar siswa dapat meningkat. Namun di lain pihak, gadget pun dapat menimbulakan dampak negatif terhadap prestasi belajar siswa.

Siswa atau anak adalah pribadi yang "unik" yang mempunyai potensi dan mengalami proses berkembang. Dalam proses berkembang itu anak membutuhkan bantuan yang sifat dan coraknya tidak ditentukan oleh guru tetapi oleh anak itu sendiri, dalam suatu kehidupan bersama dengan individuindividu yang lain.

(Ahmadi, 2003) Perkembangan menunjukkan suatu proses tertentu, yaitu proses yang menuju ke depan dan tidak dapat diualang kembali. Dalam perkembangan manusia terjadi perubahan-perubahan yang sedikit banyak bersifat tetap dan tidak dapat diulang. Perkembangan tidak ditekankan pada segi material, melainkan pada segi fungsional. Perkembangan juga menghasilkan karakteristik baru yang berlangsung melalui tahap aktivitas yang sederhana ke tahap yang lebih tinggi. Perkembangan bergerak perlahan namun pasti, yang kian hari bertambah maju mulai dari masa pembuahan dan berakhir dengan kematian.

Begitu pula dengan masa anak-anak. (Hurlock, 2016) Masa anak-anak dimulai dari bayi, yakni usia 2 tahun sampai anak matang secara seksual. Selama periode usia 11 tahun bagi perempuan dan 12 tahun bagi laki-laki terjadi perubahan yang signifikan, baik secara fisik maupun psikologis. Masa anak-anak terbagi menjadi dua tahap, yaitu masa anak-anak awal dan masa anak-anak akhir. Masa anak-anak awal dimulai sejak usia 2-6 tahun, sedangkan masa anak-anak akhir dimulai sejak usia 6 tahun sampai saat anak matang secara seksual.

Pada saat anak memasuki usia sekolah dasar yaitu umur 6-12 tahun, perkembangan anak akan sangat cepat. Bukan hanya perkembangan secara fisik, namun juga perkembangan psikologinya. Mereka akan memperoleh keterampilan fisik saat bermain, dan keterampilan dasar dalam membaca, menulis dan berhitung, juga hubungan antara keluarga serta teman sebaya.

(Fathoni, 2017) Gadget merupakan teknologi yang sangat populer sekarang ini, orang dewasa maupun anak-anak menggunakan gadget. Dimana banyak produk-produk gadget yang menjadikan anakanak sebagai target pasar mereka dan anak-anak kini telah menjadi konsumen aktif pengguna gadget. (Chusna, 2017) Gadget adalah sebuah istilah dalam bahasa Inggris yang mengartikan sebuah alat 
elektronik kecil dengan berbagai macam fungsi khusus. Gadget (Bahasa Indonesia: acang) adalah suatu istilah yang berasal dari bahasa Inggris untuk merujuk pada suatu peranti atau instrumen yang memiliki tujuan dan fungsi praktis spesifik yang berguna yang umumnya diberikan terhadap sesuatu yang baru. Gadget dalam pengertian umum dianggap sebagai suatu perangkat elektronik yang memiliki fungsi khusus pada setiap perangkatnya. Contohnya: komputer, handphone, game dan lainnya. Pada kenyataannya, ketika anak telah terlalu asik dengan dunia gadget nya, mereka akan lupa akan kebutuhan pokok anak yaitu belajar dan bersosialisasi dengan benar di kehidupan. Anak-anak sangat menikmati keasikan dalam menggunakan smartphone dalam kegiatan anak sehari-hari baik itu di rumah, lingkungan sekolah dan juga lingkungan bermain anak, sehingga sebagian anak cenderung merasa asik menikmati gadget yang dimilikinya. Bahkan anak-anak lebih asik dengan gadget daripada mendengarkan perintah orang tua. Selain itu seringkali ada yang marah jika diperintah oleh orang tua. Itulah salah satu bentuk kecanduan anak-anak terhadap gadget yang dimiliki. Memberikan gadget pada anak tanpa adanya pengawasan orang dewasa atau orang yang lebih tua memang akan cenderung menimbulkan beberapa dampak negatif. Kasus diatas telah memberikan sedikit dampak gadget pada kesehatan fisik bahkan mental anak. Mulai dari merusak penglihatan hingga anak mengalami gangguan kejiwaan yang parah. Jika anak tidak di dampingi orang tua saat bermain gadget maka akan semakin memperparah keadaan anak, bermain boleh namun jangan biarkan anak berlarut-larut dalam permainan sampai berdampak pada diri anak itu sendiri. (Warisyah, 2015) Gagdet merupakan alat elektronik yang digunakan sebagai media informasi, media belajar dan sebagai hiburan. Manfaat gadget lainnya yaitu dapat tersambung dengan internet. Siswa sekolah dasar sudah mengenal fungsi internet. Sehingga banyak siswa sekolah dasar yang menyalahgunakan penggunaan internet untuk hal negatif. Sehingga siswa harus selalu dalam pengawasan orang tua. Orang tua memberikan gadget pada anaknya dengan tujuan untuk mengenalkan games pada anaknya. Dibanding dnegan orang dewasa yang baru mengenal gadget, anak lebih cepat menguasasi gadget dari pada orang dewasa. Bahkan orang tua mereka belum tentu dapat mengoperasikan gadget yang mereka miliki. (Rachmawati et al., 2017) Gadget sendiri sudah banyak diminati oleh semua kalangan, khususunya di kalangan pelajar, gadget sudah banyak digunakan karena lebih praktis dan menyenangkan dalam proses pembelajaran. Gadget telah dilengkapi dengan fitur-fitur yang amat canggih. Hal tersebut dapat membantu gaya pembelajaran, misalnya untuk dapat mengakses sebuah situs untuk mencari artikel atau materi-materi yang sedang dijelaskan. (Marpaung, 2018) Gadget memiliki banyak manfaat apalagi digunakan dengan cara yang benar dan semestinya diperbolehkan orang tua mengenalkan gadget pada anak memang perlu tetapi harus diingat terdapat dampak positif dan dampak negatif pada gadget tersebut. Tetapi harus sadar bahwa berkomunikasi menggunakan gadget juga punya kekurangan. Gadget mengubah suara menjadi gelombang elektromagnetik seperti halnya radio. Kuatnya pancaran gelombang dan letak gadget yang menempel di kepala akan mengubah sel-sel otak hingga berkembang abnormal dan potensial menjadi sel kanker. Jadi, efek radiasi gadget sedemikian berbahaya jika sering digunakan. (Wulan Patria Saroinsong, 2016) Penggunaan gadget berdampak merugikan pada keterampilan interpersonal anak jika terlalu sering digunakan. Pengaruh handphone terhadap prestasi belajar siswa yang lain adalah siswa menjadi lebih mengandalkan handphone daripada harus belajar.

(Setianingsih, n.d.) Untuk memaksimalkan pengawasan anak saat bermain dengan gadget nya, ada beberapa hal penting yang perlu diperhatikan, yaitu: 1) menjadikan akun email pribadi orang tua sebagai akun utama anak-anak, sehingga semua kegiatan internet anak langsung terintegrasi dan terpantau di akun email orang tua, 2) untuk aplikasi sosial media, hanya ijinkan anak berteman dan mem-follow teman yang sebaya, 3) membuat peraturan No Gadget mulai bakda maghrib sampai jam sembilan malam. Ini adalah prime-time efektif anak untuk belajar, 4) untuk anak usia SD atau TK sebaiknya dibatasi anak bermain gadget tidak lebih dari dua jam per hari, 5) orang tua harus menjadi teladan dengan tidak menunjukkan intensitas tinggi dalam memakai gadget, 6) Jangan memarahi anak-anak membabi buta saat mengetahui mereka terpapar konten negatif di dunia maya. Sebaiknya beri pendampingan, pengarahan, dan penjelasan yang sesuai dan mudah dipahami oleh bahasa anak.

Survei yang dilakukan Yayasan "Kita dan Buah Hati" menyebutkan 76 persen anak kelas empat hingga enam SD di Jakarta, Bogor, Depok, Tangerang dan Bekasi sudah pernah melihat konten pornografi. Sebagian besar mengunduh konten pornografi dari rumah sendiri karena tidak sengaja, sementara sebagian anak lain mengunduh konten porno dari warnet, gadget atau dari teman (Setyawan: 2015, KPAI.go).

Sekretaris menteri Pemberdayaan Perempuan dan Perlindungan Anak, Pribudiarta Nur Sitepu mengungkapkan bahwa saat ini Kementeriaan PPPA, Kementerian Komunikasi dan Informatika, Kementerian Pendidikan dan Kebudayan, serta Kementerian Agama kini tengah menggodok regulasi pembatasan penggunaan gadget/gawai. Rencananya, regulasi akan berbentuk Peraturan Pemerintah (PP) Perlindungan Khusus amanah Pasal 59, Undang-undang Nomor 35 Tahun 2014 tentang Perlindungan Anak. Pasal tersebut merinci tentang kewajiban Pemerintah Pusat dan Daerah serta lembaga Negara 
lainnya terhadap perlindungan anak. Pada Pasal 59A dijabarkan lebih rinci mengenai upaya yang dilakukan terkait "Perlindungan Khusus" tersebut (Tashandra (2018), Kompas.com).

Pembatasan penggunaan gadget juga berlaku di sekolah. Kementerian Pemberdayaan Perempuan dan Perlindungan Anak akan membatasi penggunaan gadget selama belajar, baik di sekolah dasar, sekolah menengah pertama, dan sekolah menengah atas atau sederajat. Peraturan ini disusun dengan pertimbangan bahwa penggunaan gadget selama proses pembelajaran sangat mengganggu proses belajar dan mengajar, serta berdampak negatif bagi anak bila menggunakan gadget secara berlebihan. Peraturan ini masih dibahas oleh kementrian terkait untuk menyamakan persepsi mengenai substansi yang dimaksud. Selain itu, peraturan ini dibuat agar tidak bertentangan dengan hak anak untuk mendapatkan dan mencari informasi yang dijamin oleh,

Pasal 10 Undang-Undang Nomor 23 Tahun 2002 tentang Hak dan Kewajiban Anak.

"Setiap anak berhak menyatakan dan didengar pendapatnya, menerima, mencari, dan memberikan informasi sesuai dengan tingkat kecerdasan dan usianya demi pengembangan dirinya sesuai dengan nilai-nilai kesusilaan dan kepatutan."

Pembatasan pengunaan gadget bagi anak sekolah dirasa cukup membantu, menurut keadaan yang terjadi saat ini salah satunya di SD Muhammadiyah 11 Semarang. Seperti kasus yang didapat peneliti saat melakukan observasi, beberapa siswa kelas empat sampai enam bebas menggunakan gadget milik mereka setelah selesai belajar sembari menunggu orang tua menjemput. Siswa yang memakai gadget, biasanya digunakan untuk menonton video dari youtube atau bermain game untuk mengisi waktu selama menunggu orang tua siswa menjemput atau pesanan ojek online datang.

Pemandangan seperti ini dapat dilihat setiap hari setelah pulang sekolah. Penggunaan gadget yang tanpa pengawasan orang tua atau guru ini dapat berdampak buruk bagi siswa, karena siswa lebih sering memandang gadget daripada bermain dengan teman sebaya seperti bermain bola, atau bermain yang melakukan aktivitas fisik. Peneliti pernah mencoba mengajak berbicara pada salah satu siswa yang sedang asyik bermain game di gadget, namun jawaban yang keluar dari mulut siswa tersebut sangat lama dan terkesan enggan menjawab. Bahkan, saat ditanya oleh guru siswa juga melakukan hal yang sama dan tidak melakukan kontak mata terhadap lawan bicaranya. Jadi, dampak yang dihasilkan oleh gadget dan gadget dapat merusak karakter anak yang seharusnya baik menjadi karakter yang buruk.

Walaupun penggunaan gadget tidak dilakukan pada jam-jam belajar, hal ini perlu perhatian khusus dari guru maupun orang tua siswa. Bagi siswa yang tidak membawa atau memiliki gadget sendiri akan menimbulkan kecemburuan bagi siswa. Dengan adanya peraturan pembatasan penggunaan gadget ini diharapakan ada peningkatan efektivitas, kreativitas, dan kemandirian proses pembelajaran di satuan pendidikan serta menjadi pembinaan terhadap siswa maupun orang tua tentang bahaya penggunaan gadget secara berlebihan.

Berdasarkan uraian di atas, maka peneliti tertarik untuk mengkaji tentang dampak yang ditimbulkan terhadap penggunaan gadget dengan judul "Dampak Penggunaan Gadget terhadap perkembangan Psikologi pada Anak Sekolah Dasar di SD Muhammadiyah 11 Semarang”.

\section{Metode}

Metode penelitian ini menggunakan pendekatan kualitatif pada prinsipnya penelitian kualitatif adalah suatu prosedur untuk menghasilkan sejumlah deskripsi tentang apa yang akan ditulis dan apa yang diucapkan oleh orang yang menjadi sasaran penelitian secara deskripsi mengenai perilaku mereka yang dapat diamati. Sehingga data yang dihasilkan bukan data yang berbentuk angka-angka melainkan katakata yang bersifat deskriptif. Metode kualitatif digunakan untuk meneliti suatu kondisi obyek yang bersifat alamiah, peneliti sebagai instrumen kunci, teknik pengumpulan data dilakukan secara triangulasi (observasi, wawancara, dokumentasi), dan hasil penelitian kualitatif bersifat memahami makna, keunikan, mengkontruksi fenomena, dan menemukan hipotesis (Sugiyono, 2007).

Pendekatan kualitatif digunakan karena peneliti ingin mencari dampak penggunaan gadget terhadap perkembangan psikologi anak, baik itu dampak negatif maupun dampak positif di SD Muhammadiyah 11 Semarang.

\section{Hasil dan Pembahasan}

Memperhatikan dan menelaah hasil obserbvasi, dan wawancara secara mendalam dengan para narasumber, serta dokumentasi dan angket maka telah dipaparkan deskripsi umum tentang temuan dan hasil penelitian yang berkaitan dengan dampak penggunaan gadget terhadap perkembangan psikologi 
anak usia sekolah dasar di SD Muhammadiyah 11 Semarang. Penelitian ini dilakukan untuk menemukan dampak penggunaaan gadget terhadapa perkembangan psikologi anak sekolah dasar. Peneliti berpendapat bahwa gadget akan memberikan dampak, baik itu dampak positif maupun dampak negatif bagi anak. Peneliti juga membahas perkembangan psikologi apa yang terpengaruh oleh gadget. Ada tiga aspek dalam perkembangan psikologi anak, yaitu aspek pertumbuhan emosi, perilaku prososial dan perkembangan moral.

a. Hasil Observasi

Berdasarkan hasil observasi selama tiga hari, didapatkan hasil pengamatan yaitu siswa menunjukkan sikap merespon saat diajak bicara, menunjukkan ekspresi marah, nyaman berada didalam kelas, mampu menyelesaikan tugas di sekolah, mampu mengendalikan emosi, melaksanakan piket sesuai jadwal, menghibur teman yang bersedih, menyumbangkan sebagian uang saku, melaksanakan ibadah, menghargai orang lain, dan mampumematuhi peraturan di sekolah. Beberapa siswa mampu bersikap jujur dan menunjukkan sikap kasih sayang, namun siswa belum dapat menunjukkan sikap berbagi makanan atau alat tulis dengan teman dan memuji karya teman.

\section{b. Hasil Angket}

Hasil pengisian angket pada anak didapatkan bahwa 26\% anak dengan kategori pemakaian gadget tinggi, dengan durasi pemakaian gadget lebih dari 2 jam sehari, kategori sedang sebanyak $42 \%$ dengan durasi pemakaian gadget kurang dari 1 jam atau 40-60 menit dalam sehari, sedangkan 32\% lainnya masuk dalam kategori rendah dengan pemakaian gadget 5-30 menit dalam sehari dan sangat jarang menggunakan gadget di rumah atau hanya saat senggang saja. Sehingga, peneliti mendapatkan 10 anak yang menggunakan gadget lebih dari 2 jam dalam sehari. Anak menggunakan gadget untuk membuka Internet, youtube, dan game. Tingkat kecanduan anak beragam, seperti tangan tidak bisa diam saat tidak memegang gadget, menangis saat gadget diambil, dan sering menirukan gerakan yang ada di dalam game yang sering dimainkan. Anak bersikap baik kepada orang lain. Anak selalu berhati-hati saat berbicara dan bertingkah laku. Anak menyelesaikan pekerjaan dengan baik. Anak mampu berkomunikasi dengan baik terhadap orang-orang disekitar. Anak mampu menolong teman yang sedang mengalami musibah atau kesusahan serta memberikan motivasi atau semangat. Anak mampu menjalankan ajaran agama, seperti sholat 5 waktu, berdoa, dan melaksanakan puasa bulan Ramadhan. Anak mampu bersikap sopan santun kepada orang yang lebih tua, meminta maaf saat melakukan kesalahan, dan berkata jujur.

Hasil pengisian angket pada orang tua anak didapatkan bahwa orang tua setuju jika anak menggunakan gadget kurang dari 1 jam dalam sehari atau saat waktu luang saja. Semenjak mengenal gadget, anak menjadi sering membangkang atau membantah, lebih senang bermain gadget di rumah dibanding bermain di luar bersama teman-teman. Anak sering menunjukkan ekspresi kesal atau marah. Anak mampu beradaptasi dengan lingkungan baru, bertanggungjawab dengan tugasnya, membantu pekerjaan orang tua di rumah. Bersikap sopan santun kepada yang lebih tua, serta mematuhi peraturan di sekolah maupun di rumah.

\section{c. Hasil Wawancara}

Dari hasil wawancara anak menunjukkan bahwa anak lebih banyak menggunakan gadget untuk bermain game online dan menonton youtube, sesekali membuka internet untuk membantu belajar dan berkomunikasi melalui whatsapp. Beberapa anak dibatasi penggunaan gadget nya oleh orang tua, namun ada anak yang saat gadget diminta ia akan marah dan merajuk. Anak mengatakan bahwa gadget tidak banyak berpengaruh pada perilaku dan prestasinya di sekolah, namun saat anak bermain gadget terlalu lama, anak merasa pusing hingga mata menjadi merah dan pandangan menjadi kabur. Anak belum mampu mengendalikan emosi, dan rasa panik. Namun anak mampu beradaptasi dengan baik di lingkungan baru. Anak mampu membantu orang yang mengalami kesusahan tanpa meminta imbalan. Mampu bertoleransi antar agama, menghormati pendapat orang, berkata sopan pada orang yang lebih tua. Namun terkadang anak juga pernah melanggar aturran sekolah dan berkata kasar pada teman karena sering di ejek atau bahkan bertengkar.

Hasil wawancara dengan orang tua anak mengatakan bahwa anak menggunakan gadget unt uk bermain game online dan menonton youtube, serta sesekali menggunakan whatsapp untuk berkomunikasi dengan teman dan membuka internet untuk belajar. Gadget memiliki dampak positif bagi anak jika digunakan mencari informasi tambahan sebagai sarana penunjang belajar, serta tidak menggunakan gadget terlalu lama, agar tidak mengalami kecanduan. Selain dampak positif, ada pula dampak negatif dari gadget yaitu anak menjadi malas melakukan aktivitas fisik, anak menjadi mudah marah, saat diberi tahu anak membangkang, anak meniru tingkah laku yang ada pada game, sering berbicara sendiri ada gadget, dan membuat mata anak menjadi sakit jika terlalu lama memainkan gadget 
Hasil wawancara kepada guru dan kepala sekolah mengatakan bahwa sekolah tidak pernah mengijinkan anak membawa gadget ke sekolah. Guru juga menyarankan saat dirumah anak dibatasi penggunaannya hanya 1 jam dan di hari libur. Untuk hari biasa diperbolehkan untuk sarana belajar, namun harus dengan pendampingan orang tua. Guru menyarankan agar anak menggunakan aplikasi yang berguna untuk sarana belajar. Jika gadget digunakan dengan baik dapat membantu pelajaran, namun saat gadget hanya digunakan untuk bermain game saja akan berdampak buruk bagi anak, contohnya anak menjadi malas, kurang peduli, anak menjadi jahil, dan berpengaruh pada penglihatan anak sehingga akan mengganggu belajar anak di sekolah. Anak di kelas V belum bisa mengendalikan emosi, harus ada bimbingan dari guru. Begitu pula dalam pengambilan keputusan dan penyelesaian masalah, anak harus selalu diberi arahan dan bimbingan dari guru, bila anak tidak diarahkan anak akan bertengkar dengan temannya. Anak mempunyai perilaku sosial yang baik, seperti membantu teman yang kesusahan, menghibur teman yang bersedih, menjenguk teman yang sakit, dan secara sukarela menyumbangkan sebagian uang sakunya untuk di infaqkan. Beberapa anak akan membantah jika diberi tahu atau diberi nasehat, ada pula yang suka memotong pembicaraan guru, namun guru akan langsung menindak tegas agar anak tidak mengulangi perbatan yang kurang baik tersebut. Anak mampu menjalankan ajaran agama dengan baik, seperti sholat, dan berdoa sebelum memulai pelajaran. Anak berkomunikasi dengan sopan saat dengan guru, namun sering berbicara senaknya saat bersama dengan temannya, sehingga menimbulkan pertengkaran. Anak juga perlu pendampingan dalam meningkatkan rasa percaya diri.

\section{Simpulan dan Saran}

Berdasarkan hasil penelitian dan pembahasan pada BAB IV dapat disimpulkan bahwa penggunaan gadget berdampak pada perkembangan psikologi anak sekolah dasar. Dalam penelitian ini 10 anak di kelas V (lima) yang menggunakan gadget dengan durasi lebih dari 2 jam perhari mengalami perubahan perilaku. Dampak yang ditimbulkan yaitu dampak positif, anak mudah mencari informasi tentang pembelajaran, dan memudahkan untuk berkomunikasi dengan teman. Namun, dampak negatif yang ditimbulkan dari gadget, berpengaruh pada perkembangan psikologi anak, terutama aspek pertumbuhan emosi dan perkembangan moral. Dalam pertumbuhan emosi, anak yang menggunakan gadget menjadi mudah marah, suka membangkang, menirukan tingkah laku dalam gadget serta berbicara sendiri pada gadget. Sedangkan pengaruhnya terhadap perkembangan moral, berdampak pada kedisiplinan, anak menjadi malas melakukan apapun, meninggalkan kewajibannya untuk beribadah, dan berkurangnya waktu belajar akibat terlalu sering bermain game dan menonton youtube.

Setelah melakukan analisis dampak penggunaan gadget terhadap perkembangan psikologi anak sekolah dasar. Ada beberapa saran yang penulis sampaikan diantaranya sebagi berikut : 1) Bagi anak, diharapkan mampu mengurangi frekuensi menggunakan gadget sehingga mampu meningkatkan kemampuan anak dalam mengontrol diri untuk tidak bermain gadget berlebihan. 2) Bagi guru, diharapkan dapat memanfaatkan perangkat gadget sebagai media pembelajaran di kelas. 3) Bagi orang tua dan guru, diharapkan mampu membantu mengawasi, mendampingi, dan membatasi penggunaan gadget, serta perilaku anak yang menyimpang sehingga anak mendapatkan kemamuan untuk mengontrol perilaku maupun ucapan. 4) Bagi peneliti selanjutnya yang tertarik melakukan penelitian yang sama dengan peneliti, agar memperhatikan aspek-aspek lain dalam perkembangan psikologi anak sekolah dasar.

\section{Daftar Rujukan}

Ahmadi, A. (2003). Psikologi Umum. Pt. Asdi Mahasatya.

Ameliola, S., Nugraha, D. . (2013). Perkembangan Media Informasi Dan Teknologi Terhadap Anak Dalam Era Globalisasi. Universitas Brawijaya. Http://Icssis.Files.Wordpress.Com/2 013/09/2013-0229.Pdf

Chusna, P. A. (2017). Pengaruh Media Gadget Pada Perkembangan Karakter Anak. Dinamika Penelitian: Media Komunikasi Sosial Keagamaan, 17(2), 315-330. Https://Doi.Org/10.21274/Dinamika/2017.17.2.315-330

Fathoni, A. R. (2017). Pengaruh Gadget Terhadap Perkembangan Anak Usia Dini. Http://Www.Artikelcakep.Top/2017/10/Pengaruhgadget-Terhadap-PerkembangananakArtikelcakep.Html.

Hurlock, E. B. (2016). Psikologi Perkembangan (Suatu Pendekatan Sepanjang Rentang Kehidupan) (5th Ed). Erlangga. 
Marpaung, J. (2018). Pengaruh Penggunaan Gadget Dalam Kehidupan. Kopasta: Jurnal Program Studi Bimbingan Konseling, 5(2), 55-64. Https://Doi.Org/10.33373/Kop.V5i2.1521

Rachmawati, P., Rede, A., \& Jamhari, M. (2017). Pengaruh Penggunaan Gadget Terhadap Hasil Belajar Mahasiswa Pendidikan Biologi Angkatan 2013 Fkip Untad Pada Mata Kuliah Desain Media Pembelajaran. E-Jip Biol, 5(1), 35-40.

Setianingsih, E. S. (N.D.). “Gadget "Pisau Bermata Dua” Bagi Anak ? Seminar Pendidikan Nasional. Universitas Pgri Semarang.

Sugiyono. (2007). Statistika Untuk Penelitian (Revisi Terbaru). Alfabeta.

Warisyah, Y. (2015). Prosiding Seminar Nasional Pendidikan Pentingnya “Pendampingan Dialogis” Orang Tua Dalam Penggunaan Gadget Pada Anak Usia Dini. Proseding Seminar Nasional Pendidikan, 2016(November 2015), 130-138.

Http://Seminar.Umpo.Ac.Id/Index.Php/Semnasdik2015/Article/Download/212/213

Wulan Patria Saroinsong. (2016). Gadget Usage Inhibited Interpersonal Intelligence Of Children On Ages 6-8 Years Old. Publications, Scientific Technology, Educational, 775-781. 